\title{
Pengembangan Media Pembelajaran Berbasis Kearifan Lokal Dengan Aplikasi Prezi Di Sekolah Dasar
}

\author{
Supriyono*, Ambyah Harjanto, Putut Wisnu K, Connyta Elvadolla \\ STKIP PGRI Bandar Lampung \\ ${ }^{*}$ Corresponding Email: supri.stkippgribl@gmail.com2
}

\begin{abstract}
Abstrak
Tujuan penelitian ini adalah menciptakan dan mengembangkan pembelajaran berbasis kearifan lokal dengan aplikasi Prezi pada Pembelajaran 1 Subtema 1 Tema 8 Tempat Tinggalku Kelas IV. Jenis penelitian ini adalah Research and Development (R\&D), menggunakan langkah-langkah pengembangan menurut Borg \& Gall yang telah diubah oleh Sugiyono. Langkah-langkah pengembangan dibatasi hingga enam langkah yaitu; pengumpulan informasi potensi dan masalah, desain produk, validasi produk, perbaikan produk, uji coba produk, dan revisi produk. Persentase akhir validasi oleh ahli desain 91\% dalam kategori sangat layak. Hasil uji coba yang dilakukan adalah uji coba kelompok kecil kelas IV dengan persentase kelayakan $76 \%$ dalam kategori layak. Pada uji coba lapangan yang dilakukan pada siswa kelas IV SD Negeri 1 Rawa Laut memperoleh persentase kelayakan 79\% dalam kategori layak.
\end{abstract}

Kata Kunci:

Pengembangan, Media Pembelajaran, Aplikasi Prezi, Kearifan Lokal, Tempat Tinggalku

\begin{abstract}
The purpose of this study is to create and develop local wisdom-based learning with the Prezi application in Learning 1 Subtheme 1 Theme 8 My Place of Residence, Class IV. This type of research is Research and Development (R\&D), using development steps according to Borg \& Gall which have been modified by Sugiyono. The development steps are limited to six steps namely; potential and problem information gathering, product design, product validation, product improvement, product testing, and product revision. The final percentage of validation by design experts is $91 \%$ in the very feasible category. The results of the trials carried out were small group trials for class IV with a feasibility percentage of $76 \%$ in the feasible category. In a field trial conducted on fourth grade students of SD Negeri 1 Rawa Laut, the percentage of eligibility was $79 \%$ in the feasible category.
\end{abstract}

Keywords:

Development, Learning Media, Prezi Application, Local Wisdom, My Home

\section{A. PENDAHULUAN}

Darling-Hammond et al., (2020) mengatakan bahwa jika media dipahami secara luas, maka manusia, materi, atau peristiwa-peristiwa yang membentuk kondisi yang memungkinkan siswa memperoleh pengetahuan, keterampilan, atau sikap. Dalam hal ini guru, buku teks dan lingkungan sekolah adalah medianya. Oemar Hamalik (2015)mengungkapkan bahwa penggunaan media pembelajaran dalam proses pembelajaran dapat menimbulkan keinginan dan minat baru, motivasi dan stimulasi kegiatan pembelajaran, bahkan memiliki efek psikologis pada siswa. Manfaat praktis penggunaan media pembelajaran dalam proses belajar mengajar adalah untuk memperjelas penyajian pesan dan informasi sehingga dapat mempermudah dan meningkatkan proses dan hasil pembelajaran, dapat meningkatkan dan mengarahkan perhatian kepada anak yang dapat menimbulkan motivasi belajar, dapat 
mengatasi keterbatasan sensorik, ruang dan waktu (Azhar Arsyad, 2014).

Setiap materi pelajaran tentunya memiliki tingkat kesulitan yang berbeda-beda. Di satu sisi ada materi pelajaran yang tidak membutuhkan alat bantu, namun di sisi lain ada materi yang membutuhkan media alat peraga, seperti globe, grafik, gambar dan lain sebagainya. Materi pembelajaran dengan tingkat kesulitan yang tinggi tentunya sulit untuk diolah oleh siswa. Apalagi bagi siswa yang kurang menyukai materi pembelajaran yang disampaikan. Siswa merasa bosan dan cepat lelah tentunya tidak dapat dihindari, karena penjelasan guru sulit untuk dipahami dan dipahami. Guru yang bijaksana tentu menyadari bahwa kejenuhan dan kelelahan siswa bersumber dari penjelasan yang diberikan oleh guru yang membingungkan dan tidak fokus pada masalah yang perlu dibenahi.

Media pembelajaran yang digunakan masih terbatas. Hal tersebut menyebabkan sikap siswa yang kurang antusias saat pembelajaran, rendahnya respon tanggapan siswa atas pertanyaan dan penjelasan dari guru, kurangnya perhatian dan konsentrasi siswa serta kurangnya media yang mendukung proses pembelajaran, guru masih menggunakan karton dan styrofoam. Oleh karena itu diperlukan media pembelajaran interaktif yang dapat meningkatkan fokus siswa (Li \& Schoenfeld, 2019).

Media merupakan berbagai komponen lingkungan belajar yang digunakan untuk membantu siswa dalam belajar. Media pembelajaran dapat dipahami sebagai sarana penyampaian atau pendistribusian materi pelajaran secara terencana sehingga tercipta lingkungan belajar yang kondusif, efektif dan efisien(Apri
Wahyudi et al., 2019; DarlingHammond et al., 2020). Keberadaan media bukan satu-satunya komponen yang menjamin keberhasilan proses pembelajaran, tetapi tanpa media yang mendukung kegiatan pembelajaran tidak dapat terlaksana secara maksimal(Subandi Subandi et al., 2018). Sebagai alat bantu, media memiliki fungsi sebagai pembuka jalan untuk mencapai tujuan pengajaran. Hal ini didasarkan pada keyakinan bahwa pembelajaran dengan media membantu meningkatkan aktivitas belajar siswa dalam jangka waktu yang lama. Artinya kegiatan belajar siswa dengan bantuan media akan menghasilkan proses dan hasil belajar yang lebih baik dibandingkan tanpa bantuan media.

Prezi adalah media berbasis komputer.Prezi merupakan software presentasi sebagai sarana untuk mengeksplorasi berbagai ide pada kanvas virtual, software ini memiliki fitur unggulan yaitu menggunakan Zooming User Interface (ZUI), yang memungkinkan pengguna untuk memperbesar dan memperkecil media presentasi. Kelebihan software Prezi adalah dapat mengintegrasikan objek seperti teks, gambar, video dan media presentasi lainnya yang ditempatkan pada media presentasi, sehingga memudahkan khalayak untuk memahami isi materi presentasi(Taufiqurrahman \& Yuniastuti, 2018).

Prezi merupakan media yang dapat membantu guru untuk menyampaikan pesan yang kompleks dan menjadi lebih menarik dengan cara yang dinamis(Al-Hammouri, 2018). Sehingga siswa dapat termotivasi dalam proses pembelajaran. Media ini disertai dengan tema lebih bervariasi. Prezi juga memiliki kelebihan lebih aktif dibandingkan dengan banyak mana 
siswa mendengarkan proses pembelajaran kurang efektif untuk memvisualisasikan materi yang disajikan (Ismail et al., 2017).

\section{Penggunaan Prezi dalam Pembelajaran}

Prezi adalah perangkat lunak untuk presentasi berbasis internet. Selain presentasi, Prezi juga dapat digunakan sebagai alat untuk mengeksplorasi dan berbagi ide di atas kanvas virtual. Prezi lebih unggul karena program ini menggunakan Zooming User Interface (ZUI), yang memungkinkan penggunaan Prezi untuk memperbesar dan media memperkecil untuk menampilkan presentasi. Prezi pada awalnya dikembangkan oleh arsitek Hongaria Adam Somlai-Fischer sebagai arsitektur virtualisasi. Misi yang dikemukakan oleh Prezi adalah membuat ide lebih menarik", dan Prezi sengaja dibuat untuk menjadi alat untuk mengembangkan dan berbagi ide dalam bentuk narasi visual(Rusyfian, Z., 2016).

Perbedaan Prezi dan Power Point seperti yang telah dijelaskan sebelumnya, bahwa Prezi merupakan software yang membantu presentasi berbasis internet yang lebih unggul karena program ini telah menggunakan Zooming User Interface(ZUI) yang memungkinkan pengguna untuk memperbesar dan memperkecil presentasi Prezi. Sedangkan Microsoft Power Point merupakan salah satu program aplikasi Microsoft Office yang berguna untuk membuat presentasi dalam bentuk slide. Biasanya aplikasi ini digunakan untuk presentasi dan pengajaran, dapat dikatakan hampir semua siswa, mahasiswa, pekerja dan lainnya menggunakan software ini (Rusyfian, Z., 2016).
Tabel 1. Perbedaan antara Prezi dan Power Point

\begin{tabular}{lll}
\hline No & \multicolumn{1}{c}{ Prezi } & \multicolumn{1}{c}{ Power Point } \\
\hline & Untuk & Untuk \\
& menggunakan & menggunakan \\
& Prezi, kita sebagai & $\begin{array}{l}\text { PowerPoint, kita } \\
\text { sebagai }\end{array}$ \\
1. & pengguna harus & $\begin{array}{l}\text { pengguna tidak } \\
\text { memiliki akun }\end{array}$ \\
& Prezi terlebih harus memiliki \\
& dahulu. & akun terlebih \\
& & dahulu.
\end{tabular}

Prezi digunakan dan dibuat online

2. (menggunakan Internet) dan juga bisa online

Prezi memiliki

3. ragam tema Powerlisensi manya miliki berlisensi yang tema sederhana.

Digunakan dalam bentuk slide juga,

4. tetapi di kanvas virtual.

Program ini dilengkapi dengan en: ZUI, yang memungkinkan

Tidak ada batasan penggunaan.

5. pengguna untuk memperbesar dan memperkecil

tampilan layar presentasi.

Untuk menggunakan

Prezi dalam jangka panjang Proses instalasi

6. Anda harus bisa online atau membayar, offline. sedangkan versi publik dibatasi hingga 30 hari.

Lebih banyak slide animasi daripada Prezi

Proses

7. Prezi lebih mudah editingnya cepat, karena online. Langsung

8. Proses instalasi disimpan di 8. harus online komputer atau laptop.

9. Proses 


\begin{tabular}{|c|c|c|}
\hline No & Prezi & Power Point \\
\hline & pengeditannya & \\
\hline & lama, tergantung & \\
\hline & kekuatan Internet & \\
\hline & (online). & \\
\hline & Data yang diedit & \\
\hline 10. & disimpan di web & \\
\hline
\end{tabular}

Jika ingin menggunakan Prezi harus memiliki akun terlebih dahulu, akun ini dibuat melalui website online, cara menggunakan Prezi adalah sebagai berikut:

a) Untuk membuat akun Prezi pertama buka aplikasi browser yang dimiliki lalu masuk ke halaman web www.prezi.com lalu tekan enter.

b) Setelah masuk ke web prezi.com ada beberapa pilihan menu di bagian atas. Log adalah menu untuk masuk ke akun setelah mendaftar terlebih dahulu. Memulai digunakan untuk mulai membuat Prezi saat tidak memiliki akun di Prezi.
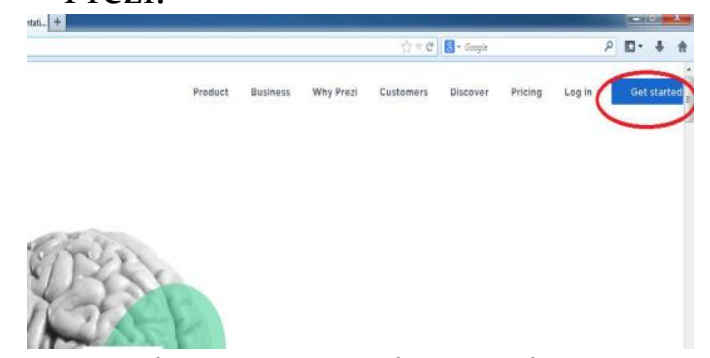

Gambar 1. Tampilan Web Prezi

c) Setelah itu ada tiga pilihan disini, basic, individual dan team, ada pilihan free dan paid. Jika kita ingin menggunakan Prezi dengan lisensi gratis kita pilih basic dan klik basic.

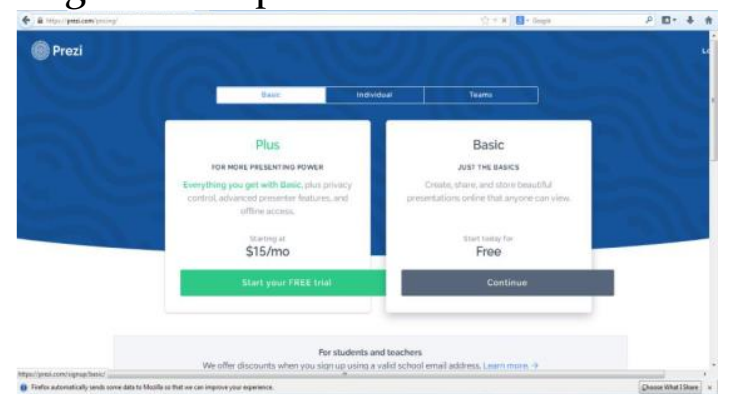

Gambar 2. Tampilkan Akun Bayar dan Gratis d) Setelah itu isikan data diri sesuai dengan kolom yang telah disediakan untuk membuat akun Prezi.

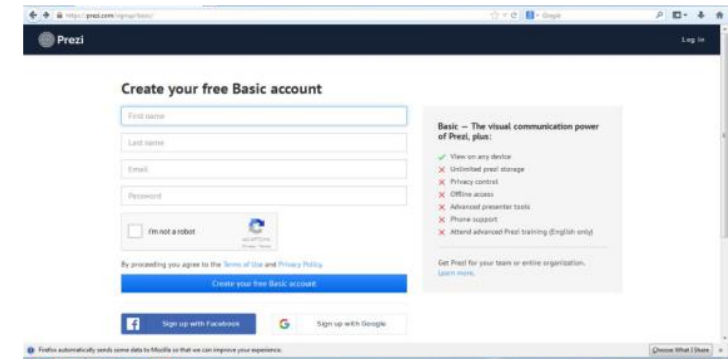

Gambar 3. Formulir Pendaftaran Akun Prezi

Isi materi media pembelajaran yang dihasilkan dalam penelitian berkaitan dengan kearifan lokal daerah Rawa Laut Bu. Sumiati(2017) mengartikan kearifan lokal sebagai kecerdasan yang dihasilkan dari pengalaman dan kepemilikan bersama. Pengalaman sendiri ini merupakan pengalaman yang dirasakan seseorang dalam masyarakat dan berlangsung terus menerus sehingga menjadi budaya. Lebih lanjut Rahyono menjelaskan bahwa setiap orang memiliki identitas yang dibangun oleh budaya, dimana didalamnya terdapat kearifan. Kearifan yang merupakan identitas suatu komunitas di daerah tersebut. Kearifan lokal memiliki posisi yang strategis.Kearifan lokal Rawa Laut $\mathrm{Bu}$ yang termasuk dalam media meliputi tempat tinggal masyarakat Rawa Laut $\mathrm{Bu}$, kegiatan yang sering dilakukan oleh masyarakat yang masih terkait dengan materi yang dimuat di media, dan lain-lain. Kearifan lokal disisipkan untuk memudahkan siswa dalam memahami materi.

\section{B. METODE}

Penelitian ini menggunakan Research and Development yang digunakan untuk membuat produk, dan menguji keefektifan produk (Sugiyono, 2017). Secara sederhana, 
Research and Development bertujuan untuk menemukan, meningkatkan, mengembangkan, menghasilkan produk, menguji produk, dan menghasilkan produk yang terstandarisasi sesuai dengan indikator yang ditetapkan. Dalam penelitian ini mengembangkan media pembelajaran berbasis kearifan lokal dengan penerapan Prezi pada Pembelajaran 1 Subtema 1 Tema 8 Tempat Tinggalku Kelas IV. Dalam penelitian ini peneliti menggunakan model Borg and Gall (Gall et al., 2014).

\section{HASIL PENELITIAN}

\section{Hasil Analisis Kebutuhan}

Dari hasil analisis kebutuhan yang dilakukan dengan observasi langsung ke sekolah dan untuk melaksanakan wawancara terhadap guru ditemukan bahwa penggunaan media pembelajaran masih terbatas, peneliti memperoleh hasil utama dari penelitian tersebut sedangkan yaitu perlunya pengembangan media pembelajaran berbasis kearifan lokal dengan aplikasi Prezi pada Pembelajaran 1 Subtema 1 Tema 8 Tempat Tinggalku Kelas IV. Penelitian dan pengembangan dilaksanakan di SD Negeri Rawa Laut Bu dan dilaksanakan di kelas IV. Dalam penelitian ini peneliti menggunakan model penelitian dan pengembangan dengan mengadaptasi metode R\&D dari Borg and Gall yang dimodifikasi oleh (Sugiyono, 2017) menjadi enam langkah.

Dalam penelitian dan pengembangan dilakukan produksi media pembelajaran berbasis kearifan lokal dengan penerapan Prezi pada Pembelajaran 1 Subtema 1 Tema 8 Tempat Tinggalku Kelas IV. Hasil analisis kebutuhan yang dilakukan adalah sebagai berikut:

\section{Hasil Tahapan Identifikasi Masalah dan Pengumpulan Data}

Hasil pada tahap identifikasi masalah dan pengumpulan data dari tinjauan pustaka dan pra penelitian dilakukan pada saat analisis kebutuhan. Secara teori ditemukan teori-teori yang mendukung kelayakan dan fungsi media Prezi sebagai media pembelajaran. Berdasarkan tinjauan pustaka, Prezi dapat menggeser paradigma pembelajaran yang semula berpusat pada guru menjadi berpusat pada siswa dan guru hanya sebagai fasilitator sehingga siswa menjadi aktif dalam pembelajaran, tidak lagi mengandalkan guru sebagai sumber tunggal. Keunggulan Prezi adalah mampu menampung keragaman gaya belajar, karena Prezi diprogramkan dapat menampilkan media visual, audio, dan animasi. Program aplikasi Prezi juga merupakan media yang unik karena didalamnya terdapat bentuk penyajian yang sangat berbeda dengan penyajian pada umumnya.

Pra penelitian atau observasi lapangan dilakukan untuk mengetahui kebutuhan guru dan siswa mengenai media pembelajaran Prezi. Observasi lapangan dilakukan dengan melakukan wawancara dengan guru, kepala sekolah dan siswa. Kriteria pertanyaan observasi adalah tentang keterampilan yang dimiliki pendidik dalam menggunakan dan mengembangkan media pembelajaran, kurikulum yang digunakan dan pendekatan yang digunakan di sekolah serta tanggapan siswa dalam menggunakan media pembelajaran Prezi.

Hasil pra penelitian atau observasi lapangan yang diperoleh adalah perlunya penggunaan media pembelajaran Prezi, dan perlunya pengembangan media pembelajaran Prezi sebagai media pembelajaran. 


\section{Hasil Desain Produk}

Berdasarkan data pra penelitian atau observasi lapangan maka spesifikasi produk yang akan dikembangkan adalah media pembelajaran berbasis kearifan lokal dengan aplikasi Prezi yang dapat membantu pendidik dan peserta didik dalam proses pembelajaran. Berikut ini adalah rencana pengembangan media pembelajaran Prezi dengan menggunakan pendekatan kearifan lokal sebagai media pembelajaran yang dikembangkan:

a. Analisis materi yang akan dibahas,

b. Menyusun media sesuai kompetensi inti, kompetensi dasar, indikator dan tujuan pembelajaran.

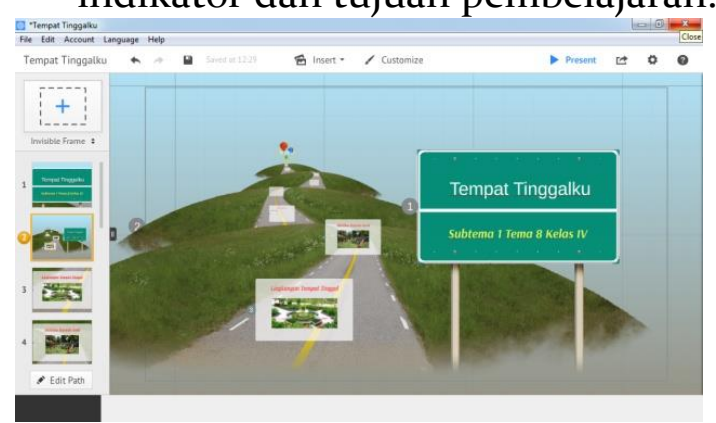

\section{Gambar 4. Cover Media} Pembelajaran

Desain Template dari media pembelajaran berbasis kearifan lokal di Prezi aplikasi untuk bahan Tempat Tinggalku.

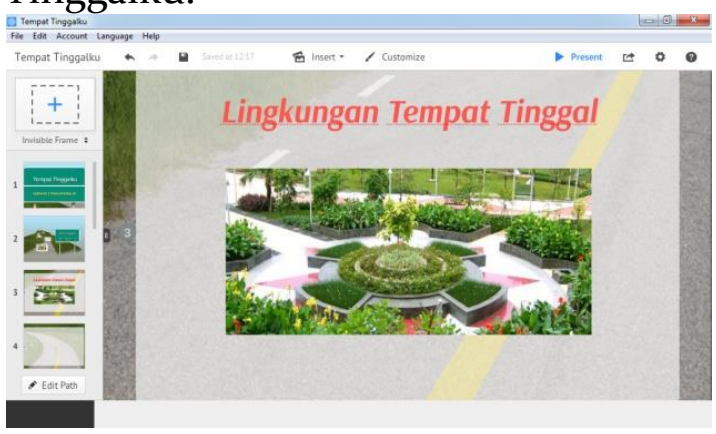

Gambar 5. Desain Template Media Pembelajaran

c. Tata media dengan mengaitkan kearifan lokal dalam Pembelajaran 1 $\begin{array}{lllll}\text { Subtema } & 1 & \text { Tema } & 8 & \text { Tempat }\end{array}$ Tinggalku Kelas IV

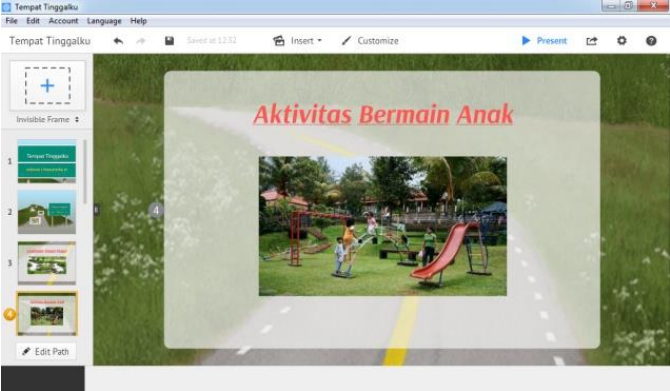

Gambar 6. Pembelajaran 1 Subtema 1 Tema 8 Tempat Tinggalku Kelas IV Berbasis Kearifan Lokal

Dalam penyusunan media pembelajaran peneliti mengaitkan kearifan lokal kawasan Rawa Laut Bu ke dalam materi yang terdapat pada media tersebut.

\section{Validasi Desain}

Setelah produk berhasil dikembangkan, langkah selanjutnya adalah menguji kelayakan model melalui validasi produk. Validasi desain atau produk dilakukan setelah pembuatan produk awal. Validasi dilakukan dalam dua macam, yaitu validasi ahli materi dan validasi ahli media. Lembar validasi diberikan oleh ahli materi dan ahli media sebagai validator.

Validasi ahli media sama dengan ahli materi yang dilakukan dengan mengisi kuesioner yang terdiri dari dua aspek yaitu aspek tampilan dan pemrograman dengan enam komponen yaitu desain layout, teks/tipigrafi, gambar, animasi, pengemasan dan penggunaan.

Penilaian oleh validasi bahan bahan di atas dapat dilihat dalam aspek pembelajaran mendapatkan persentase kelayakan dari 80\%. Validasi ahli materi dilakukan dengan mengisi lembar angket penilaian. Ada beberapa aspek penilaian yang tertuang dalam lembar validasi penilaian. Dalam setiap aspek ada beberapa pernyataan. Dari 2 aspek tersebut terdapat empat belas pernyataan yang diisi oleh ahli materi. 
Penilaian validasi materi terhadap materi di atas dapat dilihat pada aspek tampilan mendapatkan persentase kelayakan sebesar 90\%.

\section{Hasil Revisi Desain (Produk Awal)}

Setelah validasi produk dilakukan oleh validator ahli materi dan ahli media maka diperoleh saran dari validator. Kemudian saran yang diberikan digunakan sebagai masukan untuk merevisi desain produk awal. Hasil revisi desain dapat dijelaskan sebagai berikut: Hasil revisi ahli materi berupa perbaikan saran media pembelajaran berbasis kearifan lokal dengan penerapan Prezi pada Pembelajaran 1 Subtema 1 Tema 8 Tempat Tinggalku Kelas IV menurut validator.

Validator ahli materi untuk media pembelajaran berbasis kearifan lokal dengan aplikasi Prezi pada materi seni sosial. Hasil revisi ahli media berupa perbaikan dari saran media pembelajaran berbasis kearifan lokal dengan penerapan Prezi pada Pembelajaran 1 Subtema 1 Tema 8 Tempat Tinggalku Kelas IV menurut validator. Validator ahli media pada media pembelajaran berbasis kearifan lokal dengan aplikasi Prezi pada materi seni sosial.

\section{Efektivitas Media (Pengujian Produk)}

Uji coba media pembelajaran berbasis kearifan lokal dengan aplikasi Prezi materi aritmatika revisi ini dilaksanakan di satu sekolah. Uji coba mencakup uji coba kelompok kecil dan uji coba lapangan. Sidang ini dilakukan selama proses belajar, setelah belajar dengan media pembelajaran berbasis kearifan lokal dengan para Prezi aplikasi dalam Social aritmatika siswa materi diminta untuk mengisi kuesioner respon. a) Uji Coba Kelompok Kecil

Uji coba kelompok kecil produk media pembelajaran berbasis kearifan lokal dengan aplikasi Prezi pada Pembelajaran 1 Subtema 1 Tema 8 Tempat Tinggalku Kelas IV sebanyak 10 orang, siswa diberikan angket penilaian media pembelajaran berbasis kearifan lokal dengan aplikasi Prezi pada Pembelajaran 1 Subtema 1 Tema 8 Tempat Tinggalku Kelas IV, dan siswa diminta mengisi angket validasi yang telah disediakan. Total persentase kelayakan semua aspek adalah $76 \%$

b) Uji Coba Lapangan (Uji Coba Kelompok Besar)

Uji coba lapangan dilakukan di SD Negeri Rawa Laut Bu. Tujuan dari uji coba adalah untuk mendapatkan gambaran respon siswa terhadap media pembelajaran berbasis kearifan lokal dengan aplikasi Prezi pada siswa kelas IV SMP pada Pembelajaran 1 Subtema 1 Tema 8 Tempat Tinggalku Kelas IV. Langkah awal yang dilakukan peneliti adalah menampilkan media pembelajaran berbasis kearifan lokal dengan aplikasi Prezi pada Pembelajaran 1 Subtema 1 Tema 8 Tempat Tinggalku Kelas IV dengan bantuan LCD proyektor, peneliti menjelaskan materi tentang aritmatika kepada siswa. Kegiatan terakhir adalah memberikan angket untuk mengevaluasi tanggapan siswa terhadap media. jumlah total semua aspek per aspek adalah 79\% dan jumlah total persentase kelayakan.

\section{PEMBAHASAN}

Dalam menerapkan nilai-nilai kearifan lokal seperti mengangkat keragaman budaya lokal dapat menjadikan generasi muda memiliki tanggung jawab terhadap lingkungan. Salah satu upaya penerapan nilai-nilai kearifan lokal dalam pembelajaran di 
sekolah adalah melalui pengembangan media pembelajaran berbasis kearifan lokal sekitar. Upaya tersebut diperlukan untuk meningkatkan pemahaman siswa dalam proses pembelajaran melalui sumber-sumber pengetahuan yang ada di sekitarnya.

Pembelajaran yang dilakukan dengan memanfaatkan sumber-sumber pengetahuan yang ada disekitarnya akan memudahkan dalam memahami materi yang disajikan. Sebab, penerapan ilmu yang didapat dari sekolah dapat dilihat secara nyata untuk kepentingan dan manfaat lingkungan sekitarnya. Berdasarkan penelitian sebelumnya tentang pengembangan media melalui multimedia desktop Prezi memiliki tingkat keefektifan dan daya tarik yang tinggi (Hartini et al., 2017). Penelitian lain tentang pengembangan (Aruan et al., 2020)dapat disimpulkan bahwa penelitian dan pengembangan produk berupa buku teks berbasis kearifan lokal didasarkan pada hasil ahli materi dan ahli media serta pengujian produk pada aspek sistematis, kesesuaian isi, pengembangan materi, perkembangan kognitif, penggunaan bahasa, ilustrasi harmoni, akhlak, dan idiom kedaerahan standar dapat meningkatkan motivasi belajar siswa.. Sehingga Prezi dan kearifan lokal dapat digunakan sebagai salah satu upaya untuk meningkatkan motivasi belajar siswa.

\section{E. KESIMPULAN}

Media pembelajaran berbasis kearifan lokal telah dikembangkan dengan penerapan aplikasi Prezi pada Pembelajaran 1 Subtema 1 Tema 8 Tempat Tinggalku Kelas IV SD dengan mengumpulkan data kearifan lokal Lampung dengan mengambil dokumentasi berupa foto dan informasi yang terkait dengan kearifan lokal sebagai materi pada slide Prezi. Pengembangan media pembelajaran berbasis kearifan lokal dengan penerapan Prezi pada Pembelajaran 1 Subtema 1 Tema 8 Tempat Tinggalku Kelas IV layak digunakan dalam pembelajaran. Kelayakan produk berdasarkan penilaian ahli materi dan ahli media dengan penilaian $80 \%$ pada kategori layak dan 91\% pada kategori sangat layak. Hasil uji coba yang dilakukan pada kelompok kecil kelas IV dengan persentase kelayakan $76 \%$ dalam kategori layak. Uji coba lapangan yang dilakukan pada siswa kelas IV SD Negeri 1 Rawa Laut, memperoleh persentase $79 \%$ dalam kategori layak.

\section{DAFTAR PUSTAKA}

Al-Hammouri, S. (2018). The Effect of Using Prezi on Al Zaytoonah University Students'

Performance in French Language Reading Skills. International Education Studies, $12(1)$, 128. https://doi.org/10.5539/ies.v12n1 p128

Apri Wahyudi, Zulela, Arita Marini, Choirudin, B. Ayshwarya, Phong Thanh Nguyen, \& K. Shankar. (2019). Government Policy in Realizing Basic Education Metro. International Journal of Innovative Technology and Exploring Engineering (IJITEE), $8\left(9 \mathrm{~S}_{3}\right), 113-116$.

Aruan, L., Sari, R., \& Bengar Harahap, A. (2020). Using Prezi Online Software to Improve Teaching Listening Skill. International Journal of Education and Literacy Studies, $\quad 8(1), \quad 104$. https://doi.org/10.7575/aiac.ijels. v.8n.1p.104 
Azhar Arsyad. (2014). Media Pembelajaran. PT RajaGrafindo Persada.

Darling-Hammond, L., Flook, L., CookHarvey, C., Barron, B., \& Osher, D. (2020). Implications for educational practice of the science of learning and development. Applied Developmental Science, 24(2), 97-140.

https://doi.org/10.108o/10888691 .2018 .1537791

Gall, M. D., Gall, J. P., \& Borg, W. R. (2014). Applying Educational Research: How to Read, Do, and Use Research to Solve Problems of Practice. Pearson Education.

Hartini, S., Misbah, M., Dewantara, D., Oktovian, R. A., \& Aisyah, N. (2017). Developing Learning Media Using Online Prezi into Materials about Optical Equipments. Jurnal Pendidikan IPA Indonesia, 6(2), 313. https://doi.org/10.15294/jpii.v6i2 .10102

Ismail, Z. H., Matzin, R., Jawawi, R., Shahrill, M., Jaidin, J. H., Mundia, L., \& Mahadi, M. A. (2017). The Effectiveness of Using an Online Presentation Platform in the Teaching and Learning of History. Silpakorn University Journal of Social Sciences, Humanities, and Arts, 17(2), 75-96.

Li, Y., \& Schoenfeld, A. H. (2019). Problematizing teaching and learning mathematics as "given" in STEM education. International Journal of STEM Education, 6(1), 44 . https://doi.org/10.1186/s40594019-0197-9

Oemar Hamalik. (2015). Kurikulum dan Pembelajaran. PT Bumi Aksara.
Rusyfian, Z. (2016). Prezi Solusi Presentasi Masa Kini. Informatika.

Subandi Subandi, Choirudin Choirudin, Mahmudi Mahmudi, Nizaruddin Nizaruddin, \& Hermanita Hermanita. (2018). Building Interactive Communication with Google Classroom. International Journal of Engineering $\mathcal{E}$ Technology, 7(2.13), 46o-463.

Sugiyono. (2017). Metode Penelitian Kuantitatif, Kualitatif, dan RED. CV. Alfabeta.

Sumiati, D. (2017). Intercultural Communication Based on Local Wisdom That Made the People of Bali Reject Sharia Tourism. Asian Journal of Media and Communication (AJMC), 1(2), 137-146.

Taufiqurrahman, M., \& Yuniastuti. (2018). Pengembangan Media CD Pembelajaran Berbasis Prezi Pada Pokok Bahasan Globalisasi Mata Pelajaran Pkn Kelas IX MTsN Bangsal, Mojokerto. 12. 